\title{
ARTIFICIAL BUFFERS DO NOT INHIBIT CONTRACTILE RESPONSES IN THE SMOOTH MUSCLE OF RAT PORTAL VEIN AND GUINEA PIG TAENIA COLI
}

\author{
Hideaki KARAKI, Tadahiko SUZUKI and Norimoto URAKAWA \\ Department of Veterinary Pharmacology, Faculty of Agriculture, \\ University of Tokyo, Bunkyo-ku, Tokyo 113, Japan
}

Accepted July 10,1981

\begin{abstract}
Effects of substitution for $\mathrm{NaHCO}_{3}$ (and $5 \% \quad \mathrm{CO}_{2}$ ) in the physiological solution with equimolar $\mathrm{N}$-2-hydroxyethylpiperazine- $\mathrm{N}^{\prime}-2$ ethanesulfonic acid (HEPES) or morpholinopropane sulfonic acid (MOPS) (and $100 \% \mathrm{O}_{2}$ ) at various $\mathrm{pH}$ levels on the contractility of smooth muscle were examined. At pH 7.4, spontaneous contraction in rat portal vein was not inhibited by the artificial buffer solutions, as compared to findings in the case of bicarbonate buffer solution. Norepinephrine-dose response curve in the case of rat portal vein and the histamine-dose response curve in cases of guinea pig taenia coli remained unchanged in the artificial buffer solutions. At pH 7.2 and 7.0, the spontaneous contraction in portal vein was reversibly inhibited either in artificial or in bicarbonate buffer solutions. The norepinephrine- and histamine-dose response curves shifted downwards and/or to the right in these low pH solutions. Thus. HEPES and MOPS had no inhibitory effect on the smooth muscle contractility. Since low $\mathrm{pH}$ strongly inhibited the contractility, attention should be directed to the temperature-dependent decreases in pKa of the artificial buffers (i.e., if $\mathrm{pH}$ of the solution is adjusted at room temperature and then warmed, $\mathrm{pH}$ decreases).
\end{abstract}

Artificial buffer substances such as tris (hydroxymethyl) aminomethane (tris) and zwitterionic buffers have been widely used in various biological experiments when a bicarbonate buffer was not appropriate. These artificial buffers have also long been used in the studies of excitation-contraction coupling in smooth muscle. Recently. Altura and collaborators reported that the substitution for bicarbonate buffer system with tris or zwitterionic buffer systems markedly attenuated spontaneous mechanical activity in rat portal vein and also inhibited agonistinduced contractions in rat portal vein and aorta (1-3). Since the reduction in the concentration of $\mathrm{HCO}_{3}{ }^{-}$under $\mathrm{CO}_{2}$ aeration
( $\mathrm{pH}$ maintained at 7.4 by adding $\mathrm{NaOH}$ ) had little effect on the smooth muscle contraction (3). they concluded that the artificial buffer substances have a strong inhibitory effect on the smooth muscle contractility (1-3). However, their experimental plan to reduce external $\mathrm{NaHCO}_{3}$ concentration without changing $\mathrm{pH}$ is not appropriate since the addition of $\mathrm{NaOH}$ in the presence of $\mathrm{CO}_{2}$ aeration results in a formation of $\mathrm{NaHCO}_{3}$. Further, in previous studies (4-7), we found no inhibitory effect of tris on the smooth muscle contractions induced under different circumstances. In the present report, we examined the effects of N-2-hydroxyethylpiperazine- $N^{\prime}$-2-ethanesulfonic acid 
(HEPES) and morpholinopropane sulfonic acid (MOPS) on the contractility of rat portal vein and guinea pig taenia coli.

\section{MATERIALS AND METHODS}

Longitudinal segments of portal vein (approximately $5 \mathrm{~mm}$ long) were dissected from decapitated Wistar rats weighing 250$300 \mathrm{~g}$. Pieces of taenia coli $(20-25 \mathrm{~mm}$ long) were also isolated from male guinea pigs weighing $250-300 \mathrm{~g}$. The muscle strips were isometrically mounted under a resting tension of $500 \mathrm{mg}$ for portal vein and $200 \mathrm{mg}$ for taenia.

The bicarbonate buffer solution contained (mM) NaCl 136.8, $\mathrm{KCl} 5.4, \mathrm{CaCl}_{2} 2.5$. $\mathrm{MgCl}_{2}$ 1.0. glucose 5.5 and $\mathrm{NaHCO}_{3} 25.0$ and was aerated with $95 \% \mathrm{O}_{2}$ and $5 \% \mathrm{CO}_{2}$ mixture at $37^{\circ} \mathrm{C}$ and $\mathrm{pH}$ 7.4. In some experiments, the concentration of $\mathrm{NaHCO}_{3}$ was reduced to $12.0 \mathrm{mM}$ or to $6.0 \mathrm{mM}$ in order to decrease the $\mathrm{pH}$ of the solution to 7.2 or 7.0, respectively. Artificial buffer solutions were prepared by replacing the $25 \mathrm{mM} \mathrm{NaHCO}_{3}$ in the above solution with equimolar HEPES or MOPS and neutralized to $\mathrm{pH} 7.4,7.2$ or 7.0 with $\mathrm{NaOH}$ and were aerated with $100 \% \mathrm{O}_{2}$. Since $\mathrm{pKa}$ values for HEPES and MOPS decrease with the increase in temperature $\left(-0.014 /{ }^{\circ} \mathrm{C}\right.$ for HEPES and $-0.006 /{ }^{\circ} \mathrm{C}$ for MOPS), as is the case with tris $\left(-0.031 /{ }^{\circ} \mathrm{C}\right), \mathrm{pH}$ of these solutions was carefully adjusted at the experimental temperature $\left(37^{\circ} \mathrm{C}\right)$.

Cumulative dose-response curves to norepinephrine (NE) and to histamine were obtained initially in bicarbonate buffer solution with $\mathrm{pH} 7.4$ and subsequently in the modified solutions after a $60 \mathrm{~min}$ incubation in the latter solution. Although we confirmed in preliminary experiments that the dose-response curves were reproducible in the bicarbonate buffer solution with $\mathrm{pH} 7.4$. only one of the modified solutions was tested only once with each muscle pre- paration to avoid possible degeneration in the contractility in the modified solutions. The Student's $t$-test was used to obtain significant differences.

The chemicals used were HEPES (Wako Pure Chemicals Industries, Ltd., Tokyo), MOPS (Sigma Chemicals Co., St. Louis, M.O.), NE (bitartrate, Wako) and histamine (dihydrochloride, Wako).

\section{RESULTS}

Effects of buffer substances and $\mathrm{pH}$ on spontaneous contraction in potral vein: In bicarbonate buffer solution with $\mathrm{pH} 7.4$, the portal vein showed spontaneous rhythmic contractions with an average frequency of $2.7 \pm 0.2 / \mathrm{min}$ and an average tension of $490 \pm 30 \mathrm{mg}(n=20)$. When incubating the portal vein with HEPES buffer solution with $\mathrm{pH}$ 7.4, the frequency of the spontaneous contractions transiently increased. However, 5-10 min after changing the solution, both frequency and tension returned to the levels in the bicarbonate buffer solution $(2.9 \pm 0.5 /$ $\mathrm{min}$ and $515 \pm 45 \mathrm{mg}, \mathrm{n}=5$ ). Typical results of the experiments are shown in Fig. 1 (upper trace). Similar results were obtained

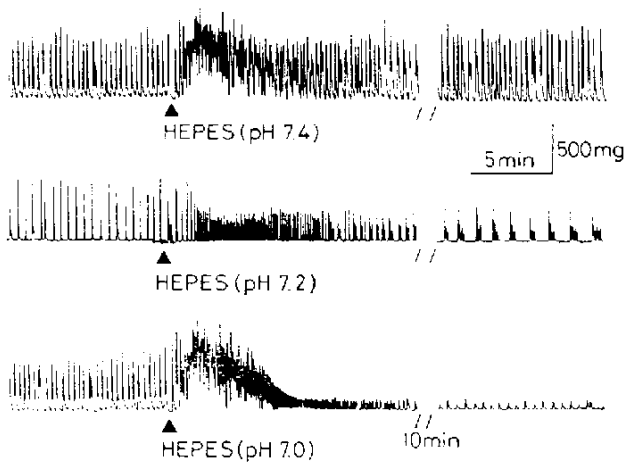

Fig. 1. Effects of HEPES buffer solution with $\mathrm{pH}$ 7.4, 7.2 or 7.0 on spontaneous contractions in isolated rat portal vein. The portal vein was initially equilibrated in bicarbonate buffer solution with pH 7.4. Subsequently, the solution was changed with HEPES buffer solution with pH 7.4, 7.2 or 7.0 . 
with MOPS buffer solution with $\mathrm{pH} 7.4$ $(2.2 \pm 0.4 / \mathrm{min}$ and $506 \pm 61 \mathrm{mg}, \mathrm{n}=5)$. These results suggest that neither absence of bicarbonate ion nor addition of $25 \mathrm{mM}$ HEPES or MOPS has any inhibitory effect on the spontaneous activity of portal vein.

When decreasing the $\mathrm{pH}$ of the HEPES buffer solution to 7.2, the average spontaneous contractile tension decreased to $354 \pm 27 \mathrm{mg}(n=5)$ and the shape of the contractions sometimes changed as shown in Fig. 1 (middle trace). Further decrease in $\mathrm{pH}$ to 7.0 more strongly inhibited the spontaneous contraction (Fig. 1. lower trace). Both tension and frequency of the spontaneous contractions returned to the control level when the $\mathrm{pH}$ of the solution was increased to 7.4. Similar results were obtained with bicarbonate buffer solution and MOPS buffer solution with low $\mathrm{pH}$. Thus, low pH markedly attenuated the spontaneous contractions, irrespective of the buffer substances examined.

In taenia, spontaneous contractions of irregular shape and size were observed in bicarbonate buffer solution with $\mathrm{pH}$ 7.4. The spontaneous activity did not change in HEPES or MOPS buffer solution with $\mathrm{pH}$ 7.4 although the activity was greatly attenuated in the low $\mathrm{pH}$ solutions.

Effects of buffer substances and $\mathrm{pH}$ on $\mathrm{NE}$-induced contraction in portal vein and histamine-induced contraction in taenia coli: As shown in Fig. 2, NE-dose response curves in case of the portal vein were not affected by the change in buffer substances at $\mathrm{pH} 7.4$. Decreasing the external $\mathrm{pH}$ to 7.2 and 7.0 , the dose response curves shifted to the right and/or to the downwards, irrespective of the buffer substances used. As shown in Fig. 3 . similar results were obtained in histaminedose response curves in case of the taenia coli.

\section{DISCUSSION}

Since Altura and collaborators reported
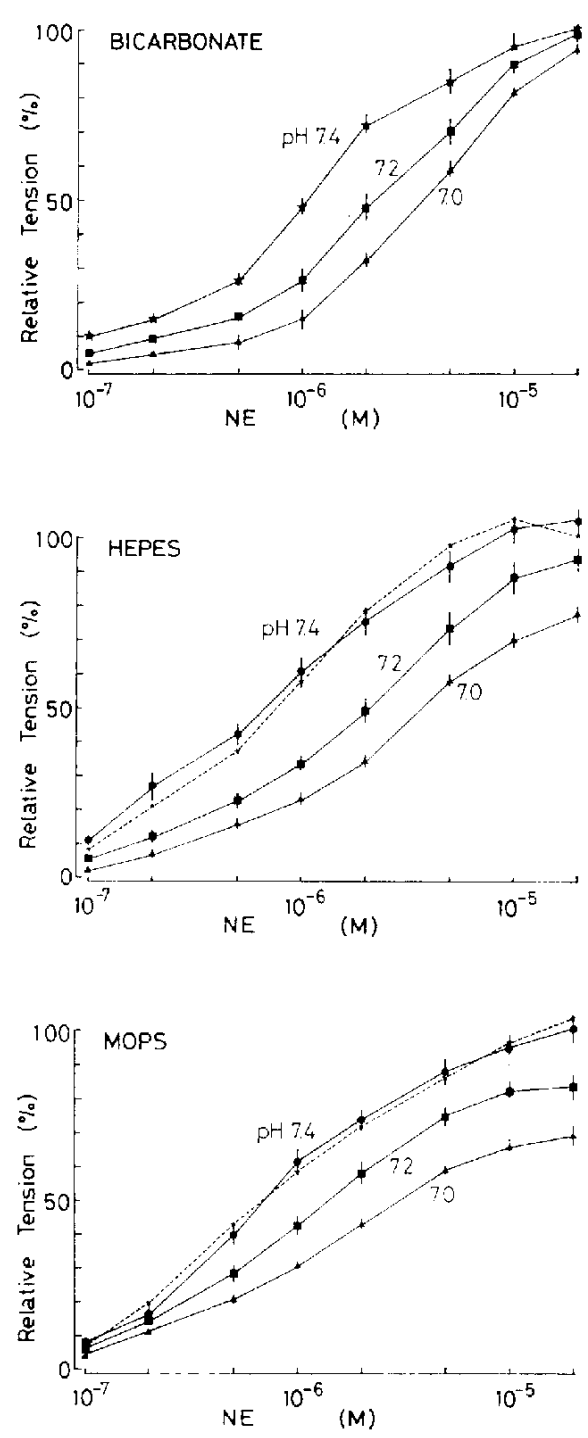

Fig. 2. Effects of bicarbonate (upper), HEPES (middle) or MOPS (lower) buffer solutions with $\mathrm{pH} 7.4 .7 .2$ or 7.0 on cumulative dose-response curves in relation to norepinephrine (NE) in rat portal vein. Six portal veins were used to obtain each curve. Only one of the modified solutions was tested only once with each muscle preparation following the incubation with bicarbonate buffer solution with $\mathrm{pH} 7.4$ (control solution). The control dose-response curve obtained in the control solution is shown by the dotted line in the middle and the lower figures. The contractile tension obtained by $2 \times 10^{-5} \mathrm{M} N E$ in the control dose-response curve was taken as $100 \%$ in the ordinate. Each point represents mean $\pm S$.E. 
the strong inhibitory effects of tris on the contractile response as we $\mathrm{II}$ as on the uptake of ${ }^{45} \mathrm{Ca}$ in smooth muscle of rat portal vein and aorta $(1-3,8)$, different investigators
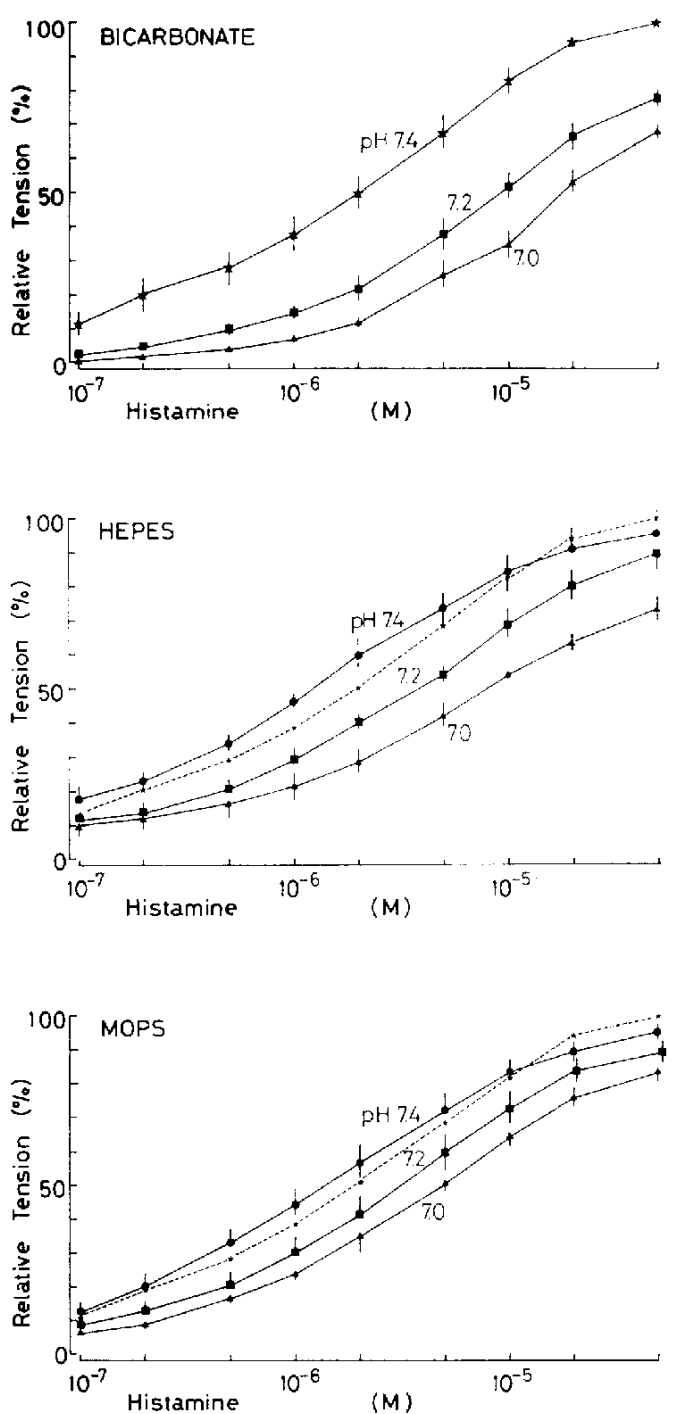

Fig. 3. Effects of bicarbonate (upper), HEPES (middle) or MOPS (lower) buffer solutions with $\mathrm{pH} 7.4,7.2$ or 7.0 on cumulative doseresponse curves in relation to histamine in taenia coli. Experimental procedures were the same as those in Fig. 2 except that the contractile tension obtained by $5 \times 10^{-5} \mathrm{M}$ histamine in the control dose-response curve was taken as $100 \%$. Each point represents mean \pm S.E. of six experiments. questioned their conclusion. Johansson et al. (9) did not find any inhibitory effect of tris on the spontaneous contractility of rat portal vein and suggested that the $\mathrm{pH}$ of the tris buffer solution used in the Altura's laboratory might be lower than that of the bicarbonate buffer solution. The temperature-dependent change in pKa of tris is $-0.031 /{ }^{\circ} \mathrm{C}$ and if the $\mathrm{pH}$ of the tris buffer solution was adjusted to 7.4 at room temperature $\left(20^{\circ} \mathrm{C}\right)$ and then warmed to $37^{\circ} \mathrm{C}$, the $\mathrm{pH}$ would decrease to 6.87. Further, no inhibitory effect of tris was found in rat tail artery (10), rabbit main pulmonary artery (11), rabbit aorta (6) and in rat portal vein and aorta (7). On the effect of tris on ${ }^{45} \mathrm{Ca}$ movement. Turlapaty et al. $(3,8)$ compared the bicarbonate buffer solution containing phosphate ion and the tris buffer solution without phosphate ion and reported ${ }^{45} \mathrm{Ca}$ retention by smooth muscle was less in the tris buffer solution. Karaki and Weiss (6) examined the effects of phosphate ion on ${ }^{45} \mathrm{C}$ a retention and concluded that phosphate increases ${ }^{45} \mathrm{Ca}$ retention by smooth muscle either in bicarbonate buffer or in tris buffer solution. They (6) suggested that the observation by Turlapaty et al. $(3,8)$ is not attributable to the inhibitory effect of tris but rather to the effect of phosphate ion.

The results obtained in the present experiments indicate that not only tris but also HEPES and MOPS have no inhibitory effect on the contractility of two different types of smooth muscle and that the absence of bicarbonate ion does not attenuate the contractility. It was also reported that histidine buffer has no inhibitory effect on the contractions in rabbit taenia (12). The only difference between bicarbonate buffer and artificial buffers reported so far is that the intracellular $\mathrm{pH}$ of smooth muscle was lower in bicarbonate buffer solution than that in tris buffer solution although $\mathrm{pH}$ of both solutions were identical (5). Such a 
difference in intracellular buffering might affect smooth muscle function (5) although the contractility was not affected. The present results also confirmed earlier reports (12-15) that decrease in $\mathrm{pH}$ of the solution strongly attenuates smooth muscle contractility. The inhibitory effect of low $\mathrm{pH}$ is explained by a $\mathrm{H}^{+}-\mathrm{Ca}^{++}$competition which inhibits $\mathrm{Ca}^{++}$ influx (15). Since the pKa value of most of the artificial buffer substances decrease with the increase in temperature, care should be taken to adjust the $\mathrm{pH}$ of the artificial buffer solutions at the experimental temperature The temperature-dependent change in $\mathrm{pKa}$ of MOPS is small $\left(-0.006 /{ }^{\circ} \mathrm{C}\right)$. We have no other explanation for the difference in conclusions obtained by Altura et al. (1) and our own group.

\section{REFERENCES}

1) Altura, B.M., Altura, B.T., Carella, A. and Turlapaty, P.D.M.V.: Adverse effects of artificial buffers on contractile responses of arterial and venous smooth muscle. Brit. J. Pharmacol. 69, 207-214 (1980)

2) Turlapaty, P.D.M.V., Altura, B.T. and Altura, B.M.: Influence of Tris on contractile responses of isolated rat aorta and portal vein. Am. J. Physiol. 235, H208-H213 (1978)

3) Turlapaty, P.D.M.V., Altura, B.T. and Altura, B.M.: Interaction of Tris-buffer and ethanol on agonist-induced responses of vascular smooth muscle and on ${ }^{45}$ calcium uptake. J. Pharmacol. exp. Ther. 211, 59-67 (1979)

4) Karaki, H., Ganeshanandan, S.S., Ikeda, M. and Urakawa, N.: Changes in tension, Ca movement and metabolism of guinea pig taenia coli in varying concentrations of external $\mathrm{Na}$ and $\mathrm{K}$. Japan. J. Pharmacol. 19, 569-577 (1969)

5) Karaki, H. and Weiss, G.B.: Effects of transmembrane $\mathrm{pH}$ gradient changes on potassium- induced relaxation in vascular smooth muscle. Blood Vessels 18, 36-44 (1981)

6) Karaki, H. and Weiss, G.B.: Rabbit aortic contractile responses and ${ }^{45} \mathrm{Ca}$ retention in tris and bicarbonate buffers. Archs int. Pharmacodyn. Thér. 252, 29-39 (1981)

7) Karaki, H., Suzuki, T. and Urakawa, N.: Tris does not inhibit isolated vascular or intestinal smooth muscle contraction. Am. J. Physiol. 241, H337-H341 (1981)

8) Turlapaty, P.D.M.V., Altura, B.T. and Altura, B.M.: Tris (hydroxymethyl) aminomethane inhibits calcium uptake in vascular smooth muscle. Biochim. Biophys. Acta 551, 459-462 (1979)

9) Johansson, B., Ljung, B., Hellstrand, P., Uvelius, B. and Sigurdsson, S.B.: Effects of tris on vascular smocth muscle, (letter to editor). Am. J. Physiol. 237, H410-H411 (1979)

10) Webb, R.C., Vanhoutte, P.M. and Bohr, D.F.: Calcium efflux in rat tail artery during potassiuminduced relaxation. Proc. Soc. exp. Biol. Med. $164,252-256$ (1980)

11) Haeusler, G., Kuhn, H. and Thorens, S.: The effect of tetraethylammonium chloride on calcium fluxes in smooth muscle from rabbit main pulmonary artery. J. Paysiol. 303, 225-241 (1980)

12) Löquist, J. and Nilsson, $E_{\text {: }}$ influence of acidbase changes on carbachol- and potassiuminduced contractions of taenia coli of the rabbit Acta physiol. scand. 111, 58-68 (1981)

13) Karaki, H., Urakawa, N. and Ikeda, M.: Influences of external magnesium, bicarbonate and phos. phate on potassium-induced contracture of the guinea pig taenia coli. Japan. J. Pharmacol. 16. 423-437 (1966)

14) Deth, R. and van Breemen, C.: Relative contributions of $\mathrm{Ca}^{2+}$ influx and cellular $\mathrm{Ca}^{2+}$ release during drug induced activation of the rabbit aorta. Pflügers Arch. 348, 13-22 (1974)

15) van Breemen, C., Farinas, B.R., Gerba, P. and McNaughton, E.D.: Excitation-contraction coupling in rabbit aorta studied by the lanthanum method for measuring cellular calcium influx. Circulation Res. 30, 44-54 (1972) 